\title{
Contrasting Root System Structure and Belowground Interactions between Black Spruce (Picea mariana (Mill.) B.S.P) and Trembling Aspen (Populus tremuloides Michx) in Boreal Mixedwoods of Eastern Canada
}

\author{
Claudele Ghotsa Mekontchou 1,*(1), Daniel Houle ${ }^{2,3}$, Yves Bergeron ${ }^{1}$ (D) and Igor Drobyshev 1,4 \\ 1 Chaire Industrielle CRSNG-UQAT-UQAM en Aménagement Forestier Durable, Institut de Recherche sur les \\ Forêts, Université du Québec en Abitibi-Témiscamingue (UQAT), 445 boul. de l'Université, \\ Rouyn-Noranda, QC J9X 5E4, Canada; Yves.Bergeron@uqat.ca (Y.B.); igor.drobyshev2@uqat.ca (I.D.) \\ 2 Direction de la Recherche Forestière, Ministère des Forêts, de la Faune et des Parcs du Québec, 2700 rue \\ Einstein, Sainte-Foy, QC G1P 3W8, Canada; daniel.houle@mffp.gouv.qc.ca \\ 3 Consortium on Regional Climatology and Adaptation to Climate Change (Ouranos), 550 rue Sherbrooke \\ Ouest, Montreal, QC H3A 1B9, Canada \\ 4 Southern Swedish Forest Research Centre, Swedish University of Agricultural Sciences, P.O. Box 49, \\ 23053 Alnarp, Sweden \\ * Correspondence: claudele.ghotsamekontchou@uqat.ca
}

Received: 14 December 2019; Accepted: 19 January 2020; Published: 21 January 2020

check for updates

\begin{abstract}
This study explored the underground interactions between black spruce and trembling aspen in pure and mixed stands to understand how their soil resource use help these species coexist in the boreal mixedwoods of Western Quebec. We analyzed species-specific fine root foraging strategies (root biomass and root tissue density) along three soil layers (organic, top 0-15 cm, and bottom 15-30 cm mineral soil), using 180 soil cores. We collected cores in three sites, each containing three $20 \times 50 \mathrm{~m}^{2}$ plots of pure spruce, pure aspen, and mixed spruce and aspen stands. Spruce had a shallow rooting, whereas aspen had a deep rooting in both types of stands. Compared to pure spruce stands, spruce had a lower fine root biomass (FRB) and a higher root tissue density (RTD) in the organic layer of mixed stands. Both patterns were indicative of spruce's more intensive resource use strategy and competitive advantage over aspen in that layer. Aspen FRB in the organic soil did not differ significantly between pure and mixed stands, but increased in the mineral soil of mixed stands. Since we did not observe a significant difference in the nutrient content of the mineral soil layer between pure aspen and mixed stands, we concluded that aspen may experience competitive exclusion in the organic layer by spruce. Aspen exhibited an extensive nutrient uptake strategy in the organic layer of mixed stands: higher FRB and lower RTD than spruce. In mixed stands, the differences in aspen rooting patterns between the organic and mineral layers suggested the use of contrasting nutrient uptake strategies along the soil profile. We speculate that the stronger spatial separation of the roots of spruce and aspen in mixed stands likely contribute to a higher partitioning of their nutrient uptake along the soil profile. These results indicate the competitive exclusion of aspen by spruce in boreal mixedwoods, which likely occurs in the soil organic layer.
\end{abstract}

Keywords: diversity-productivity relationships; nutrient uptake strategy; fine root biomass; root tissue density; stand compositional diversity 


\section{Introduction}

Understanding the relationship between diversity and productivity in forest ecosystems is critical to quantifying ecosystem responses to past and future environmental variability. A consistent and positive relationship between these two variables has been demonstrated on the global scale [1-3] in temperate and tropical forests [4-7]. Forest stands with high structural and species richness support a greater diversity of species (understory vascular plants, birds, insects, and mammals) and functions [8,9], and have greater productivity [10-13]. More diverse stands have been shown to exhibit a higher resilience to environmental variability [14-16]. On the other hand, a few studies have highlighted an insignificant or even negative effect of species diversity on forest productivity $[17,18]$ and tree growth [14]. Earlier studies of biodiversity-productivity relationships (BPR) in boreal mixedwoods focused primarily on the effects of variability in climate [14,19] and light conditions [17]. Evaluating variability in tree diameter and volume growth, these studies indicated the potential role of competition, facilitation, and niche complementarity in shaping tree productivity $[12,20,21]$. Apart from theoretical interest, a mechanistic model explaining BPR in the boreal forest could be of critical importance in developing silvicultural practices in boreal mixedwoods.

Black spruce and trembling aspen are two of the most dominant and economically-valuable species in the boreal forests of eastern Canada [22,23]. These species have broadly different habitat requirements and successional trajectories, and are hypothesized to temporally coexist in the stands in the absence of fire [24] because of the competitive exclusion of aspen by spruce over time. These ecological considerations, the absence of a general trend concerning BPR [20,25], and the concern of operationalizing tree harvest in mixed stands of the two species have led forest managers to opt for monosilvicultural practices (clearcutting on $\sim 85 \%$ of the total harvested area in Canada [26]). The growing evidence of a positive species mixing effect on stand productivity [12] and resilience to major disturbances, such as fire [27] and insect outbreaks [28,29], including the projected northward shift in the range of distribution of aspen with future climate conditions [30,31], calls for the consideration of silvicultural practices focused on mixed stands.

Aspen (TA) and spruce (BS) can modify their environment through the impact of their litter and root system on soil chemistry [10]. As compared to pure spruce stands, mixed stands of spruce and aspen have higher soil fertility, due to increases in soil temperature, humidity, nutrient content, and $\mathrm{pH}$. In turn, this leads to a positive relationship between aspen abundance in mixed stands and the total stand productivity [25], despite a negative effect of spruce on aspen growth [20]. The accumulation of spruce litter and reduced rates of its decomposition in mixed stands of spruce and aspen compared to pure aspen stands [10] could be among the factors behind such a negative effect on aspen growth. The use of soil nutrients appears to be the central element in species interactions affecting growth rates, species geographic distribution, and nutrient cycling within forest stands. However, the contribution of underground interactions has seldom been quantified, and their effects on productivity remain to be demonstrated.

Underground interactions between tree species occur through the effect on the availability of resources, chemical signaling, and the secretion of allelochemical compounds [32]. These can either be positive, neutral, or negative [33]. Positive interactions exhibit themselves when one species has a positive effect on other species by increasing the availability of soil nutrients [34,35], whereas negative interactions occur through resource depletion, allelopathy, or interference competition [36-38]. These mechanisms can simultaneously occur in the same plant community [39]. Therefore, there is a need to consider resource competition and the physiological response of plants to competition in order to better understand the underground interactions between species in mixed forest stands.

Fine roots are of immediate importance for tree nutrient uptake [40], and their biomass, tissue density, nutrient content, and distribution along the soil profile have been viewed as proxies for nutrient uptake strategies [41-45]. The filling of soil volume by fine roots (hereafter referred to as fine root biomass) has been shown to reflect nutrient availability [44,46], and has an impact on tree aboveground biomass production [47], ultimately determining tree competitive ability for resources [48,49]. On 
the other hand, the root tissue density (RTD, the amount of structural material invested by the unit volume of roots) is related to the availability of nutrients, and reflects the response of species to competition for resources [50]. Root biomass and tissue density are, therefore, essential metrics which define species' underground niche, in terms of its resource use [42,48].

We tested for differences in root foraging strategies between black spruce and trembling aspen, by analyzing their fine root biomass and tissue density along the soil profile in pure and mixed stands. We tested the general hypothesis that species coexistence in ecosystems is maintained through differences in resource use [51]. More specifically, we first hypothesized (H1) that the two species have different rooting depth (shallow for spruce and deep for aspen) in pure stands. Second, based on the concept of "functional equilibrium" [52], we hypothesized (H2) that the fine root biomass of spruce will decrease in mixed stands, and that $(\mathrm{H} 3)$ the fine root biomass of aspen will increase in mixed stands. The functional equilibrium hypothesis assumes that in ecosystems subject to nutrient stress, plants will allocate more biomass towards the roots to enhance the uptake of resources when nutrients availability becomes limiting, and contrarily when soil fertility increases. Since the nutrient content increases mostly in the organic layer of mixed stands compared to pure spruce stands [10], we hypothesized that (H4) the spruce would exhibit lower FRB and higher root tissue density, and that the opposite pattern would be observed in aspen in the organic layer of mixed stands, compared to pure spruce and pure aspen stands. We expected, therefore, an intensive nutrient uptake strategy for spruce and extensive strategy for aspen, which are characterized by generally low and high carbon investments in root production, respectively [50,53-55]. Finally, we hypothesized that (H5) the increasing aspen FRB in mixed stands compared to pure aspen stands would lead to a stronger spatial separation of spruce and aspen roots (shallower for spruce and deeper for aspen), and consequently, contrasting nutrient uptake strategies in different soil horizons. Knowledge about such a pattern will help guide future forest management decisions in the boreal zone of Quebec.

\section{Materials and Methods}

\subsection{Study Area}

The study area was located in the black spruce-feathermoss bioclimatic domain in north-western Quebec $\left(49^{\circ} 08^{\prime} \mathrm{N}\right.$ to $49^{\circ} 11^{\prime} \mathrm{N}$ and $78^{\circ} 46^{\prime} \mathrm{W}$ to $\left.78^{\circ} 53^{\prime} \mathrm{W}\right)$. The boreal forest in the area is dominated by black spruce, which grows on deep clay soils developed from proglacial deposits of Barlow and Ojibway lakes at the time of their maximum expansion during the Wisconsonian glaciation [56]. The mean annual temperature and total annual precipitation of the study area are $1.5^{\circ} \mathrm{C}$ and $675.7 \mathrm{~mm}$, respectively [57]. Fires and insect outbreaks are the primary factors of natural forest dynamics in the area. Selected stands were growing on moderately dry, clay-dominated soil [58], and originated from the same fire that occurred in the area in ca. 1916 [10].

The studied sites (three in total) were between 2 and $15 \mathrm{~km}$ away from each other (Figure 1). We established three $20 \times 50 \mathrm{~m}^{2}$ ( $0.1 \mathrm{ha}$ ) rectangular samples plots in each site, whereby each represented a stand which was uniform in terms of topography and vegetation. These comprised one pure (monodominant) stand of trembling aspen, one pure black spruce, and one mixed stand (Figure 1). 


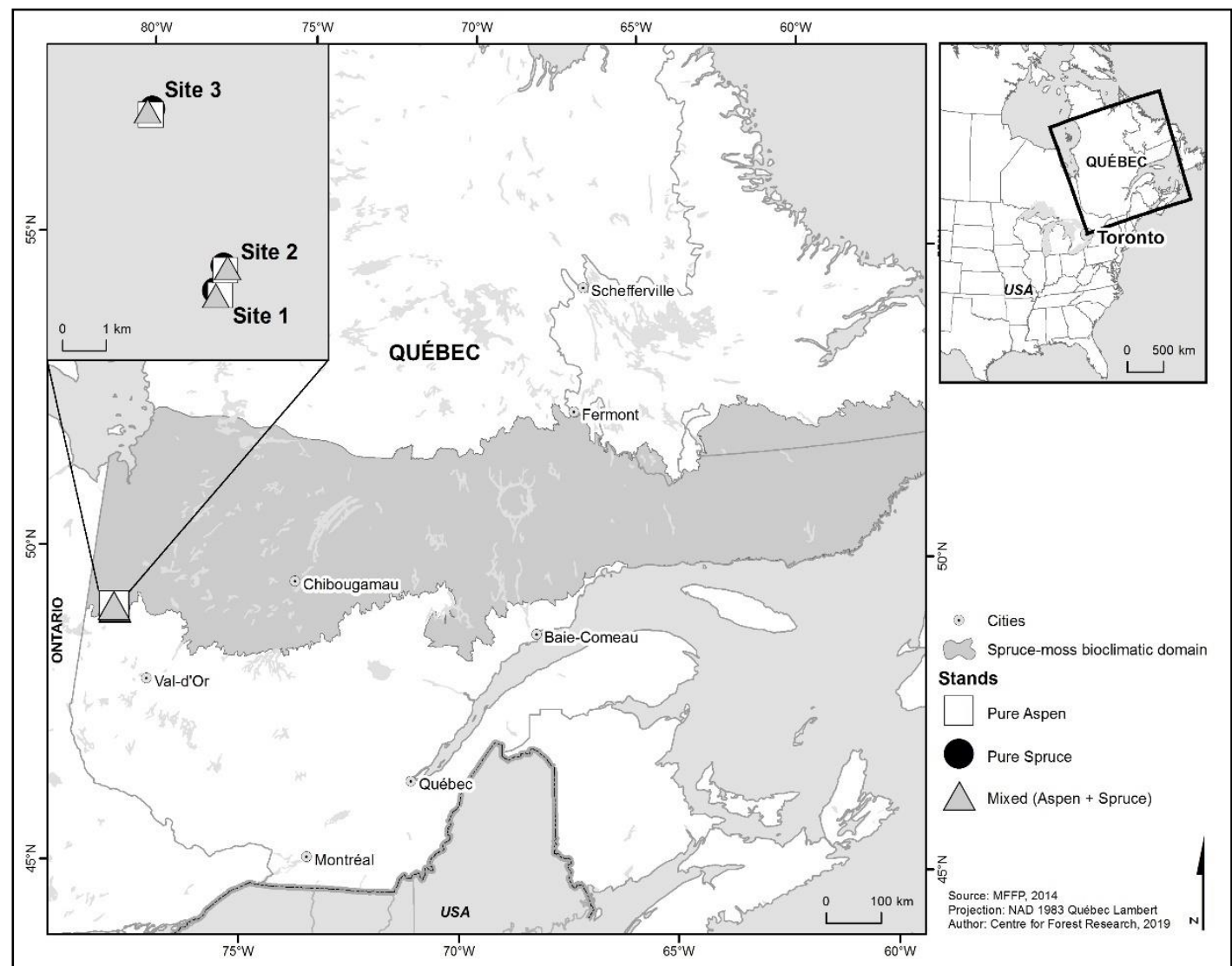

Figure 1. Location of the study sites in the spruce feathermoss bioclimatic domain of Quebec.

The selection criteria for stand types were similar to those of the previous studies investigating tree species' mixing effects in natural forest stands, i.e., pure stands had more than $80 \%$ of the stand basal area made up by a single species, whereas in mixed stands, none of the species had a basal area beyond $80 \%$ of the total stand basal area $[47,59]$. Our selection criteria also followed the definition for pure stands in the Quebec forest resource inventory. There, a single conifer species should contribute to more than $75 \%$ of stand basal area for the stand to be classified as pure, while in mixed stands, $25 \%$ to $50 \%$ stand basal area should be composed of coniferous trees [60]. To validate the attribution of stand type, we recorded diameter at breast height (DBH), i.e., at $1.3 \mathrm{~m}$, for all trees above $10 \mathrm{~cm}$, and calculated the basal area (BA) and density of each species (Table 1).

Selected stands had an overstory dominated by healthy aspen or/and spruce, the same age of the dominant canopy cohorts (100 years; [10]), low proportions of jack pine (Pinus banksiana Lamb.) in the canopy $(<15 \%$ ) and balsam fir (Abies balsamea (L.) Mill.) in the understory (field observation), and low abundance of Sphagna on the forest floor. These stand properties have been reported to influence the biomass of fine roots [59,61] and nutrient partitioning [62] in boreal forests. The selected plots were at least $150 \mathrm{~m}$ away from any other sampled point in a given site (Figure 1). We selected mixed stands within a transition zone of two pure stands of BS and TA. The $150 \mathrm{~m}$ distance between the two stands was designed to avoid border effects. To this end, we kept in mind the results of an earlier study, where the effect of aspen on the soil's physical and chemical properties was reported to persist within a distance of $7 \mathrm{~m}$ from a trembling aspen-dominated stand [10]. 
Table 1. Characteristics of sampled stands. BS, TA, and M refer to pure spruce, pure aspen, and mixed stands, respectively.

\begin{tabular}{|c|c|c|c|c|c|c|c|c|c|c|}
\hline & & \multicolumn{3}{|c|}{ Site 1} & \multicolumn{3}{|c|}{ Site2 } & \multicolumn{3}{|c|}{ Site 3} \\
\hline & & BS & TA & $\mathbf{M}$ & BS & TA & $\mathbf{M}$ & BS & TA & $\mathbf{M}$ \\
\hline \multirow{6}{*}{$\begin{array}{l}\text { Species proportion } \\
\text { (\% number of } \\
\text { stems })\end{array}$} & $\begin{array}{l}\text { Populus } \\
\text { tremuloides } \\
\text { Michx. }\end{array}$ & 2 & 60 & 34 & 2 & 70 & 38 & 2 & 74 & 43 \\
\hline & $\begin{array}{l}\text { Picea mariana } \\
\text { Mill. }\end{array}$ & 83 & 33 & 50 & 89 & 22 & 51 & 97 & 20 & 54 \\
\hline & $\begin{array}{l}\text { Abies balsamea } \\
\text { (L.) Mill. }\end{array}$ & & 6 & 3 & & 2 & & & 6 & 1 \\
\hline & $\begin{array}{c}\text { Pinus banksiana } \\
\text { Lamb. }\end{array}$ & 15 & 1 & 10 & 9 & 5 & 11 & 1 & & 1 \\
\hline & $\begin{array}{c}\text { Betula papyrifera } \\
\text { Marshall }\end{array}$ & & & 1 & & & & & & 1 \\
\hline & $\begin{array}{c}\text { Populus } \\
\text { balsamifera L. }\end{array}$ & & & 2 & & 1 & & & & \\
\hline $\begin{array}{c}\text { Density } \\
\left(\text { stems ha }{ }^{-1}\right)\end{array}$ & & 3100 & 1410 & 1160 & 3000 & 1220 & 1610 & 2382 & 900 & 1680 \\
\hline \multirow{7}{*}{$\begin{array}{l}\text { Organic soil layer } \\
\text { properties }\end{array}$} & $\mathrm{pH}$ & 3.8 & 4.0 & 4.9 & 4.2 & 5.0 & 4.7 & 3.6 & 5.01 & 4.4 \\
\hline & $\begin{array}{l}\text { Total C } \\
\left(\mathrm{g} \mathrm{kg}^{-1}\right)\end{array}$ & 311 & 194.2 & 301.2 & 337.7 & 321.5 & 321.2 & 376.2 & 287.2 & 348.7 \\
\hline & $\begin{array}{l}\text { Total N } \\
\left(\mathrm{g} \mathrm{kg}^{-1}\right)\end{array}$ & 7.8 & 10.5 & 13.7 & 10.67 & 11.5 & 11.8 & 7.7 & 17.3 & 11 \\
\hline & $\begin{array}{l}\text { Mineral N } \\
\left(\mathrm{mg} \mathrm{kg}^{-1}\right)\end{array}$ & 29.2 & 31.7 & 27.5 & 34.2 & 43.5 & 42.0 & 22.5 & 72.0 & 37.2 \\
\hline & $\mathrm{C}: \mathrm{N}$ ratio & 39.9 & 18.3 & 21.8 & 31.6 & 26.6 & 27.1 & 48.8 & 16.6 & 31.7 \\
\hline & $\mathrm{P}\left(\mathrm{mg} \mathrm{kg}^{-1}\right)$ & 81.5 & 36.2 & 59.7 & 69.5 & 79.0 & 61.5 & 129.7 & 90.5 & 161.2 \\
\hline & $\mathrm{K}\left(\mathrm{mg} \mathrm{kg}^{-1}\right)$ & 407 & 331 & 444.7 & 552.2 & 585.7 & 480.7 & 460.7 & 524.2 & 635.7 \\
\hline $\begin{array}{c}\text { Basal area } \\
\left(\mathrm{BA}, \mathrm{m}^{2} \mathrm{ha}^{-1}\right)\end{array}$ & & 61.42 & 113.46 & 61.63 & 66.6 & 91.6 & 78.55 & 65.48 & 78.07 & 74.53 \\
\hline \multirow{6}{*}{$\begin{array}{c}\text { Basal area } \\
\text { percentage per } \\
\text { species }(\%)\end{array}$} & $\begin{array}{l}\text { Populus } \\
\text { tremuloides }\end{array}$ & 3.32 & 81.93 & 58.82 & 5.50 & 87.05 & 63.52 & 2.86 & 90.47 & 68.93 \\
\hline & Picea mariana & 72.9 & 16.11 & 26.83 & 80.00 & 7.50 & 24.26 & 96.02 & 8.47 & 29.14 \\
\hline & Abies balsamea & & 0.94 & 0.78 & & 0.27 & & & 1.06 & 0.20 \\
\hline & Pinus banksiana & 23.78 & 1.02 & 12.21 & 14.50 & 4.35 & 12.22 & 1.12 & & 0.78 \\
\hline & Betula papyrifera & & & 0.46 & & & & & & 0.25 \\
\hline & $\begin{array}{c}\text { Populus } \\
\text { balsamifera }\end{array}$ & & & 0.90 & & 0.83 & & & & 0.70 \\
\hline $\begin{array}{c}\text { Organic layer } \\
\text { depth }(\mathrm{cm})\end{array}$ & & 17.3 & 6.2 & 10.16 & 20.0 & 7.5 & 11.5 & 14.2 & 9.76 & 13 \\
\hline
\end{tabular}

C, N, P, and K in soil properties denote carbon, nitrogen, phosphorus, and potassium, respectively.

\subsection{Sample Collection and Preparation}

At each plot, 20 soil cores were extracted using a 7-cm diameter manual auger every $10 \mathrm{~m}$ along four $50 \mathrm{~m}$ long transects, spaced $4 \mathrm{~m}$ apart from each other. The sampling took place between July 15 and August 20,2016. The chosen timing broadly corresponded to the period when fine roots are at their maximum length in this part of the boreal forest [47]. We collected samples from the organic horizon 
(F and $\mathrm{H}$ layer combined) and from the top $0-15 \mathrm{~cm}$ (later referred to as Min1) and bottom 15-30 cm (Min2) of the mineral soil. The samples were placed in plastic bags, transported to the laboratory in an ice-filled cooler, and stored at a temperature of $-20^{\circ} \mathrm{C}$ prior to analyses.

The 180 soil cores were pooled per transect and for each soil horizon to form a set of 12 composite samples for each plot. The composite samples were allowed to thaw over six hours and then soaked in water for at least one hour. The mixture was then stirred carefully to separate roots from the soil particles and poured through a $750 \mu \mathrm{m}$ mesh round sieve. The sieve was suspended under a distilled water bath and shaken continuously, until the roots were free from any soil particle. The roots were collected and live and dead roots were separated, based on visual appearance and a manual extension test [47]. Live roots were light in color and resistant to breakage, whereas dead roots were a grey to dark color and were easily fragmented. We discarded dead roots from further analyses. Live fine roots were sorted by species, using a combination of morphological characteristics established from prior root reference samples collected on known younger and older trees of each studied species in the study stands. The morphological criteria used were color, size, ramification, and presence/absence of root hairs [47]. Aspen roots were less ramified, with colors ranging between white and pale, whereas the roots of coniferous trees were ramified, finer in structure, and of a color ranging between red and brown. Compared to other coniferous trees, spruce roots were more reddish in color with a black bark. Balsam fir (Abies balsamea (L.) Mill.) had roots with bark color ranging from yellowish to orange, whereas jack pine had roots with a texture similar to spruce but with a lighter, brown bark color. The presence of root hairs was mostly used to separate nontree roots (commonly with root hairs) from tree roots. We extracted only the roots of spruce and aspen based on these criteria. We discarded roots larger than $2 \mathrm{~mm}$ in diameter, measuring them with a caliper. The separated fine roots were gently dried between two filter papers at room temperature to remove water, and were immediately weighed to obtain the fine roots' fresh mass. A representative fresh root subsample per soil layer was subsequently taken per transect in each stand, in such a way that their weight would be comparable among transects [63]. Following this protocol, we took two grams of fresh live roots in the FF and in the top Min 1 soil section, whereas only $0.5 \mathrm{~g}$ was taken in the lower Min2, where fine root weights in the samples were the lowest. The composite samples were oven-dried at $60^{\circ} \mathrm{C}$ for $48 \mathrm{~h}$ and reweighed to obtain the root dry mass.

\subsection{Chemical Analysis}

An aliquot (50 g) was taken from each soil sample taken per transect and air-dried to a constant weight for a week [64], ground, and sieved $(<2 \mathrm{~mm})$. For each soil horizon layer, soils were extracted with $2 \mathrm{M} \mathrm{KCl}$ (10:1 solution soil ratio, $30 \mathrm{~min})$. Nitrate $\left(\mathrm{NO}_{3}\right)$ and ammonium $\left(\mathrm{NH}_{4}\right)$ concentrations were measured, respectively, by ion chromatography (Dionex2120i, Thermo Fisher Scientific Inc., Sunnyvale, CA, USA) and colorimetrically with a Technicon Autoanalyzer (Technicon AA2, Seal Analytical Inc., Mequon, WI, USA). Since the observed nitrate concentrations were close to the detection limit (limit of $<1 \mathrm{mg} \mathrm{kg}^{-1}$ for extractable $\mathrm{NO}_{3}$ ), we only report $\mathrm{NH}_{4}$ results. Total $\mathrm{C}$ and $\mathrm{N}$ concentrations were measured with an elemental analyzer (Carlo Erba, Milan, Italy). The bulk soil pH in water was analyzed following the method described by Carter and Gregorich [64] using a Thermo Scientific Orion $2 \mathrm{pH}$ meter (Thermo Fisher Scientific, Waltham, MA, USA). Exchangeable cations and phosphorus (P) were measured by extraction in Mehlich-3 solution [65], and were further summed to estimate the effective cation exchange capacity (CEC). A summary of these soil chemical properties is provided in the Supplementary Materials Table S1. Chemical analyses were conducted at the laboratory of organic and inorganic chemistry of the Ministry of Forests, Wildlife and Parks of Quebec. 


\subsection{Data Analysis}

\subsubsection{Metrics Calculation}

Four metrics were used to test the hypotheses. The fine root biomass (FRB) was calculated as the dry mass of living fine roots per volume of soil $\left(\mathrm{kg} \cdot \mathrm{m}^{-3}\right)$ in each sample. The vertical heterogeneity index (VHI) was assessed as the standard deviation of fine roots biomass percentages in each of the three soil horizon layers over transect. VHI indicates how fully and evenly fine roots occupy the belowground space [66]. The mixture effect ratio (Ro) was calculated as the ratio between the observed biomass $\left(B_{0}\right)$ to the expected biomass $\left(\mathrm{B}_{\text {exp }}\right)$ of fine roots in mixtures. $\mathrm{B}_{\text {exp }}$ was calculated by multiplying the fine root biomass of each species in pure stands by their respective basal area proportion in mixed stands [67]. Finally, the root dry matter content (RDMC) was derived as the ratio between root dry mass and root fresh mass, in $\mathrm{g} \cdot \mathrm{g}^{-1}$. This metric is used as a proxy of root tissue density (RTD, [63]), and represents the amount of structural material invested by unit volume of roots. RDMC is an easily measurable and less susceptible to errors metric, as compared to metrics based on image analysis [63]. A potential increase in the volume of data for roots may advance our understanding of underground interactions between plant species $[68,69]$.

\subsubsection{Statistical Analysis}

We used several approaches to test our hypotheses. First, we used (1) a repeated measures analysis of variance (repeated measures ANOVA) to analyze differences in species-specific FRB, and a Kruskal-Wallis rank test to analyze differences in species-specific RDMC. We ran layer-wise comparisons between pure and mixed stands, and comparisons of soil layers within mixed stands. We regarded data collected on the transects as "multiples samples" (repeated measures). The ANOVA consisted of a mixed model with FRB as the response variable. Stand types and transects were fixed-effect factors, and the site identity was the random factor. The normality and the homoscedasticity assumptions were met for FRB data. In contrast, for the RDMC, we performed the Kruskal-Wallis and Dunn tests using R package dunn.test, since the normality and the homoscedasticity was not met, even after $\log 10$ transformation. Second, we assessed the spatial heterogeneity of fine root distribution by comparing species-specific roots VHI between pure and mixed stands (H1). Lower VHI values are indicative of a more even distribution of fine roots with soil depth [47]. Third, we tested for the effect of species mixing on the total fine root biomass within each soil horizon layer by comparing computed Ro values with the threshold value 1 ( $\mathrm{H} 2$ and $\mathrm{H} 3$ ). Values of Ro greater than one indicate a positive effect of mixture on fine root biomass, while values below one indicate a negative effect [67]. The Ro value helped, therefore, to assess the effect of mixing upon tree rooting patterns. Fourth, to test hypotheses H4 and H5, we performed a principal component analysis (PCA) on the species rooting attributes (FRB and RDMC) and soil chemical properties of the three soil layers over transect to characterize species-specific rooting strategies in pure and mixed stands [70]. The analyzed soil chemistry included $\mathrm{C}: \mathrm{N}$ ratio, $\mathrm{pH}$, carbon $(\mathrm{C})$, total nitrogen $\left(\mathrm{N}_{\text {tot }}\right)$, ammonium $\left(\mathrm{N}_{\mathrm{m}}\right)$, phosphorus $(\mathrm{P})$, potassium $(\mathrm{K})$, and exchangeable cation (CEC) content. Finally, we performed an analysis of covariance (ANCOVA) to compare the explanatory power of each nutrient on the variation of FRB and RDMC between stand types. The ANCOVA assessed the effect of stand types (pure vs. mixed) on variation of species FRB and RDMC while considering the variability of nutrient content from one stand type to another. The analysis was performed independently for each nutrient and soil layer, since the method considers only linear association between one response variable and one explanatory variable [71]. As a regression model, the ANCOVA compared the slopes (i.e., the mixed effect) and the intercept of the regression lines (i.e., the effect of stand type) between pure and mixed stands. The model allowed us to determine whether differences in species rooting between pure and mixed stands resulted from the species mixture effect on nutrient availability. Ultimately, the analysis allowed us to test whether the two species in mixed stands retain the same rooting and nutrient uptake strategy as in their respective pure stands. 
All statistical analyses were conducted with $\mathrm{R}$, version 3.4.4 [72]. The normality and homoscedasticity assumptions were tested for all analyses, using Shapiro-Wilk and Levene tests ( $R$ package car), respectively.

\section{Results}

\subsection{Fine Root Biomass}

Spruce and aspen FRB showed a decreasing gradient with increasing soil depth (Figure 2a). Spruce FRB differed significantly between the organic and the top mineral layers in both pure spruce $(F=34.91$, $p<0.001)$ and mixed $(F=62.72, p<0.001)$ stands. As for spruce, aspen FRB was significantly different among the three soil layers in pure aspen $(F=51.51, p<0.001)$ and mixed $(F=36.9, p<0.001)$ stands.

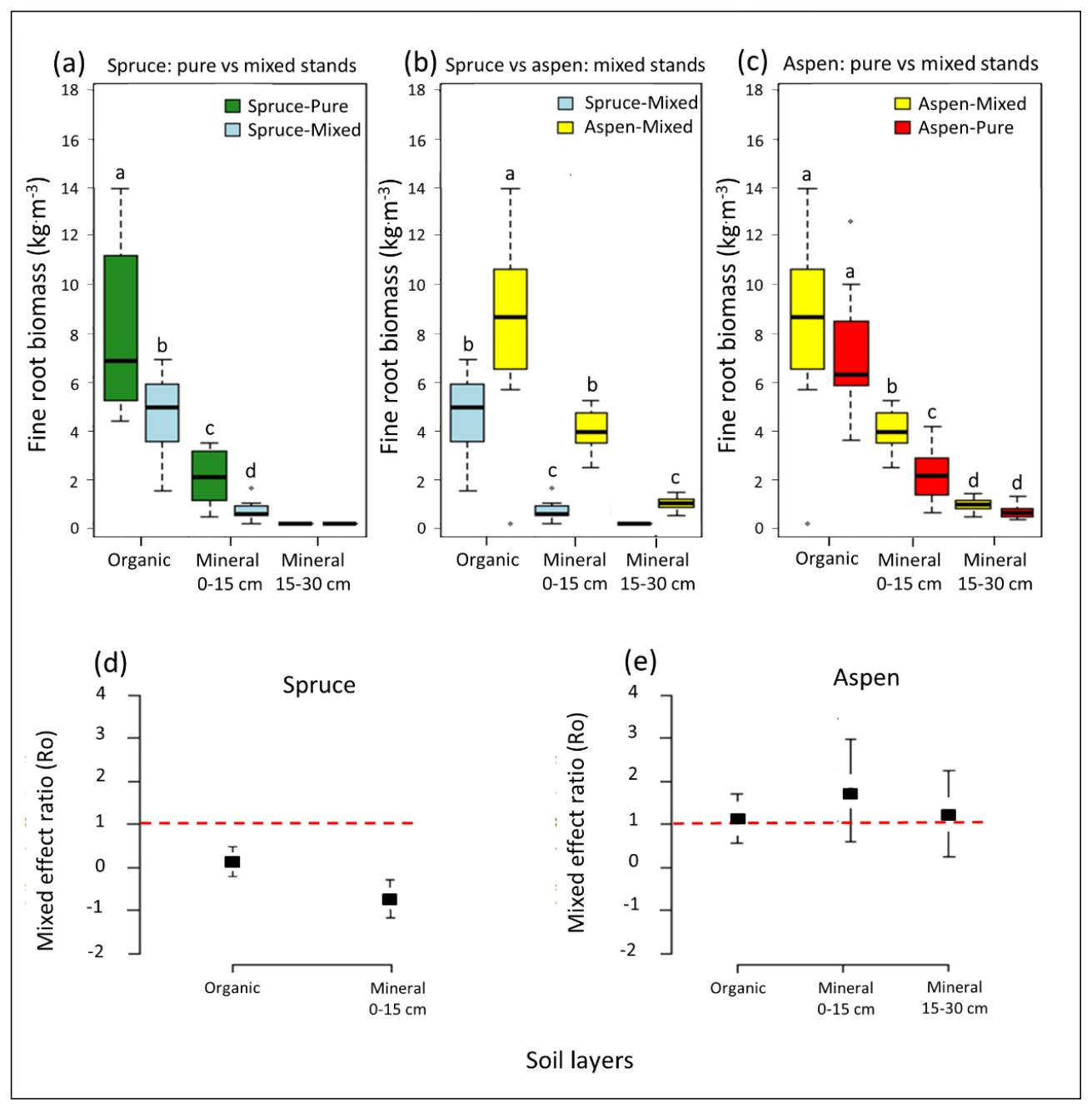

Figure 2. Differences in soil volume filling by fine roots of black spruce and trembling aspen in the three sampled soil horizon layers $(\mathbf{a}, \mathbf{c})$ between pure and mixed stands, and (b) within mixed stands. Species mixture effect on fine roots biomass of (d) black spruce and (e) trembling aspen in different soil horizon layers. In (a-c), the box represents $50 \%$ of the data set, distributed between the 2nd and 3rd quartiles. The median divides the box into the interquartile range. The lower and upper whiskers represent the minimum and maximum quartiles. For each soil layer, the number of samples $n=12$ (i.e., 3 sites $\times 4$ transects). Null values indicate that no root biomass was recorded in the soil layer on the transect. In (b), points represent average Ro values $(n=3)$, bars the $95 \%$ confidence interval, and the red dotted line the threshold under or over which the effect is considered as negative or positive. Statistical differences among pairwise comparison at $p=0.05$ within each soil layer are denoted by letters. 
The FRB of spruce decreased, while aspen FRB increased in mixed stands, compared to respective pure stands (Figure 2). The decreased spruce FRB and increased aspen FRB in mixed stands varied along soil profile (Figure $2 b$ ), and resulted from the species mixture effect (Figure 2d,e). Spruce FRB in the organic layer and in the top mineral layer was higher in pure spruce stands, and differed significantly from that of their corresponding soil layers in mixed stands (Figure 2a,c). Unlike spruce, aspen FRB in the organic and the bottom mineral layers did not differ between pure aspen and mixed stands, except in the top mineral layer (Figure 2c).

Aspen roots were more evenly distributed along soil profile than spruce roots (Figure 3). Spruce root VHI did not differ significantly between pure and mixed stands $(t=-0.95, p>0.05)$. However, the VHI values of spruce roots exhibited lower variability in mixed than in pure stands. Like spruce, aspen root VHI did not show significant difference between pure aspen and mixed stands $(t=0.17$, $p>0.05)$. The VHI values of aspen roots showed lower variability in pure stands, compared to mixed stands (Figure 3).

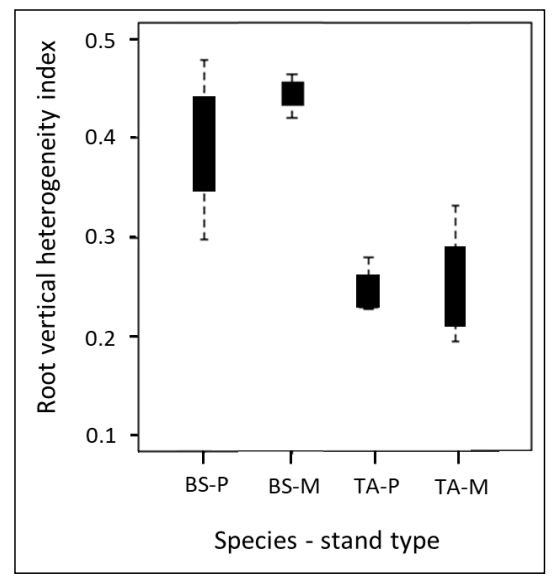

Figure 3. Fine roots vertical heterogeneity index describing how fully and evenly fine roots of black spruce (BS) and trembling aspen (TA) are distributed with soil depth in pure (P) and mixed (M) stands.

Overall, the PCA showed a shift in rooting patterns of spruce in mixed stands, compared to pure spruce stands, whereas aspen rooting did not differ between the two stand types (Figure 4).

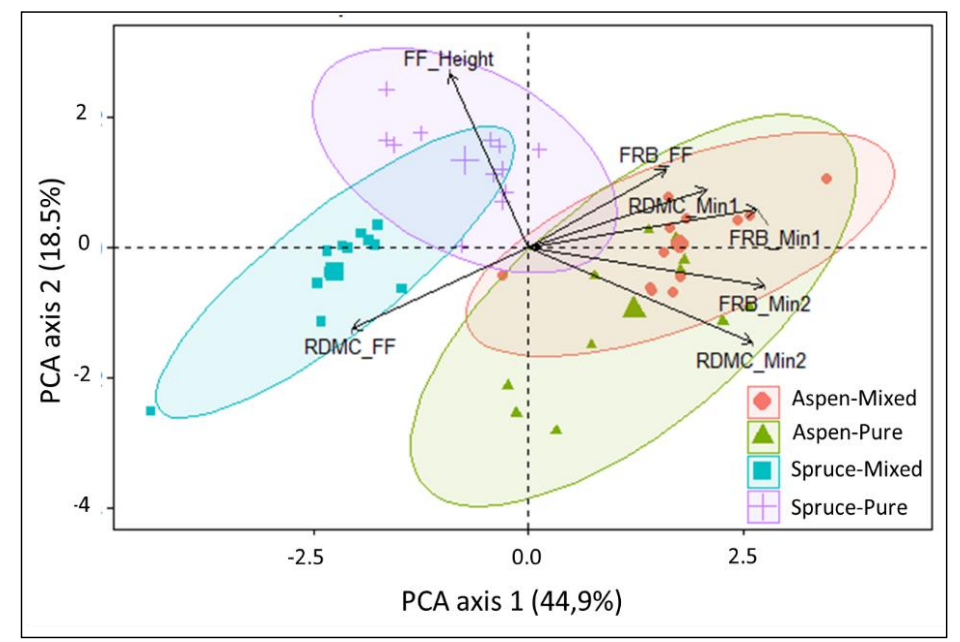

Figure 4. Principal component analysis of fine root biomass (FRB) and root dry matter content (RDMC) characterizing the rooting system of black spruce and trembling aspen in pure and mixed stands. The depth of organic horizon (FF_Height) was included in the analysis as a supplementary variable. FF, Min1, and Min2 refer to organic, mineral soil at $0-15 \mathrm{~cm}$, and mineral soil at $15-30 \mathrm{~cm}$, respectively. 
At the species-specific level, the FRB of the two species was strongly related to the variation in soil chemical properties (Figure 5, Figure S1). In the organic and top mineral layers, spruce FRB correlation with $\mathrm{pH}$, total $\mathrm{N}, \mathrm{C}: \mathrm{N}$ ratio, $\mathrm{NH}_{4}$, and $\mathrm{P}$ was stronger in pure than in mixed stands (Figure 5a). These correlations were negative for $\mathrm{pH}$, total $\mathrm{N}, \mathrm{NH}_{4}, \mathrm{~K}$, and $\mathrm{CEC}$, and positive for P. Spruce FRB in mixed stands was mostly influenced by the nutrient content of the organic layer, whereas in pure stands, it depended on both nutrient content of the organic and the top mineral horizons.

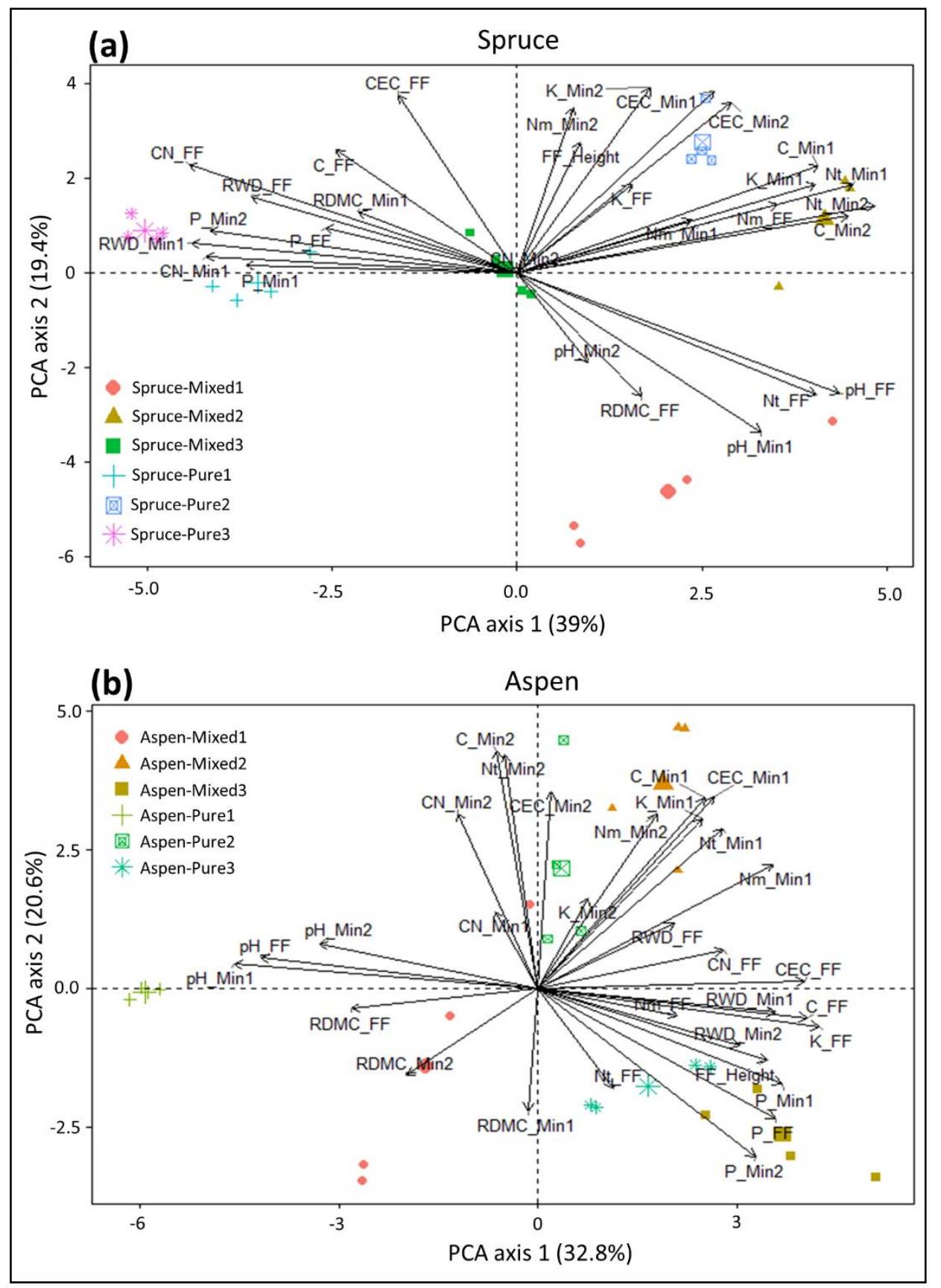

Figure 5. Principal component analysis comparing rooting patterns of black spruce (a) and trembling aspen (b) between pure and mixed stands. Variables included in the analyses are $\mathrm{C}: \mathrm{N}$ ratio, $\mathrm{pH}$, total carbon $(\mathrm{C})$, total nitrogen $(\mathrm{Nt})$, Ammonium $(\mathrm{Nm})$, phosphorus $(\mathrm{P})$, potassium $(\mathrm{K})$, exchangeable cations (CEC) and depth of the organic layer (FF height), fine root biomass (FRB), and root dry matter content (RDMC) of the two species in respective pure and mixed stands affected by site (1-3). FF, Min1, and Min2 refer to organic, mineral soil at $0-15 \mathrm{~cm}$, and mineral soil at $15-30 \mathrm{~cm}$, respectively. 
Spruce FRB showed a stronger correlation with $\mathrm{C}, \mathrm{P}, \mathrm{NH}_{4}, \mathrm{~K}$, and $\mathrm{CEC}$ in the pure than in the mixed stand ( $p$ for the effect of stand types $<0.05$; Table S2 and Figure S1). A similar pattern was observed for the effect of the depth of organic layer on spruce FRB between the two types of stands. In contrast, the $\mathrm{pH}$ and $\mathrm{C}: \mathrm{N}$ ratio showed a stronger correlation with spruce FRB in mixed than in pure stands. The observed differences were, however, not the result of species mixture effect on the availability of those nutrients ( $p$ for the mixed effect $>0.05$; Table S2), except for $\mathrm{NH}_{4}$ ( $p$ for the mixed effect $<0.05$; Table S2).

Aspen FRB was independent of nutrient content of the organic layer in pure and mixed stands, as suggested by PCA and ANCOVA (Figure $5 \mathrm{~b}$ and Figure S1). However, aspen FRB in the top and bottom mineral layers was more strongly correlated to total $\mathrm{N}, \mathrm{NH}_{4}, \mathrm{P}, \mathrm{pH}, \mathrm{K}$, and $\mathrm{CEC}$ in mixed than in pure stands ( $p$ for mixed effect $<0.05$; Table S3; Figure S1).

\subsection{Root Dry Matter Content}

The RDMC of spruce in mixed stands was significantly higher in the organic layer than in the top mineral (Figure 6a). However, in pure stands, spruce RDMC did not show a significant difference between the organic and the top mineral layers, despite the increasing trend with soil depth (Figure 6a). The RDMC of spruce in the organic layer was higher, with a greater variability in mixed than in pure stands (Figure 6a). In contrast, in the top mineral layer spruce RDMC was smaller in mixed than in pure stands (Figure 6a). No RDMC data was recorded for spruce roots in the $15-30 \mathrm{~cm}$ mineral layer of the soil, since spruce roots were limited in the organic and top $0-15 \mathrm{~cm}$ mineral layers.

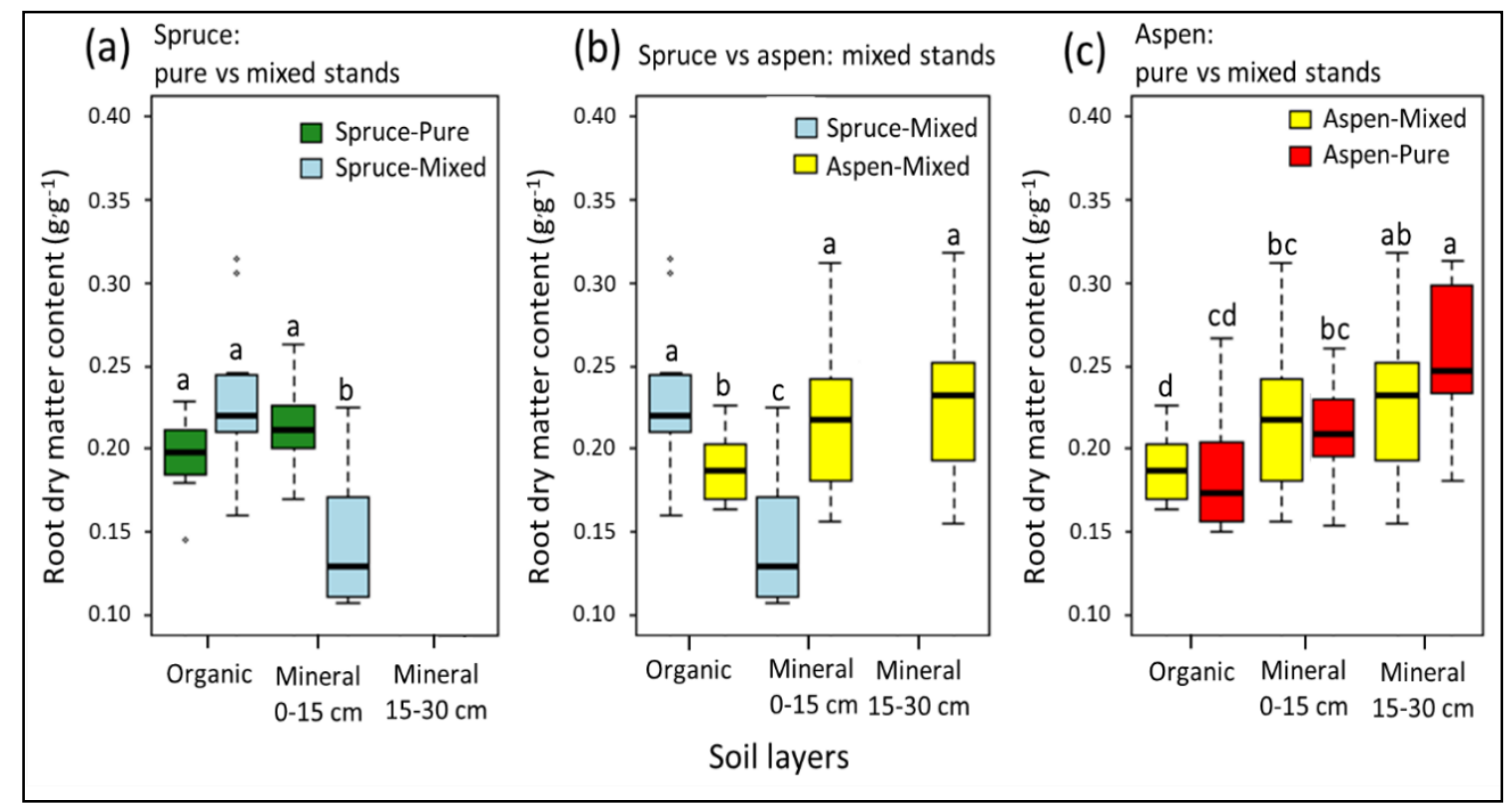

Figure 6. Differences in the root dry matter content (RDMC) of fine roots of black spruce and trembling aspen in the three sampled soil horizon layers $(\mathbf{a}, \mathbf{c})$ between pure and mixed stands, and $(\mathbf{b})$ within mixed stands. The box represents $50 \%$ of the data set, distributed between the 2 nd and 3rd quartiles. The median divides the box into the interquartile range. The lower and upper whiskers represent the minimum and maximum quartiles. Statistical differences among pairwise comparison at $p=0.05$ within each soil layer are denoted by letters.

In aspen, the RDMC increased with increasing soil depth (Figure 6c). Aspen RDMC was smaller in the organic layer than in the top mineral and bottom mineral layers in both pure and mixed stands (Figure 6c). There were, however, no significant differences in soil layer-specific RDMC between pure aspen and mixed stands (Figure 6c). Overall, spruce had a higher RDMC than aspen in the organic layer. By contrast, in the top mineral layer in mixed stands, spruce RDMC was lower than aspen 
RDMC (Figure 6b). Aspen RDMC was the highest in the bottom mineral layer (Figure $6 b, c$ ) and did not differ between pure and mixed stands (Figure 6c).

Spruce RDMC was correlated with the C:N ratio, total N, NH4, K, and $\mathrm{pH}$. The effects of those nutrients on spruce RDMC varied with stand type and soil layer (Figure 5a; Table S2). The correlation between spruce RDMC was stronger for $\mathrm{C}, \mathrm{C}: \mathrm{N}$ ratio, and $\mathrm{NH} 4$ content in the organic layer in mixed than in pure spruce stands. In contrast, in pure stands, those nutrients were strongly correlated with spruce RDMC in the top mineral horizon, as compared to mixed stands. Most of the nutrient concentrations did not differ significantly between pure aspen and mixed stands, which argued against the difference in the availability of soil nutrients as a driver of differences in aspen RDMC between the two types of stands (Table S3).

\section{Discussion}

Our results showed a shallow rooting for spruce and a deep rooting for aspen in pure stands (Figures 2 and 3), supporting hypothesis H1, i.e., that the two species have a contrasted rooting depth in their respective pure stands. We found a lower spruce fine root biomass in both the organic (23\% decrease) and mineral layers ( $45 \%$ decrease) in mixed stands, compared to pure stands. The result supported the hypothesis that mixing decreases the spruce root biomass (H2). Although aspen root biomass in the organic and the bottom mineral layers did not differ significantly between pure and mixed stands, the $25 \%$ increase in FRB recorded in the top mineral layer of mixed stands indicated a positive effect of mixing on aspen root biomass, supporting hypothesis H3. For spruce, lower root biomass and higher RDMC were associated with shallower rooting in mixed than in pure stands. We speculate that the pattern was a response of spruce to increased nutrient availability in mixed, compared to pure, spruce stands, and was indicative of an intensive resource acquisition strategy, with a more efficient use of soil resources. The result, therefore, supported H4. By contrast, aspen had deeper rooting and exhibited a contrasting nutrient uptake strategy in the organic layer in both mixed and pure aspen stands, as compared to spruce. The similarity between the rooting pattern (fine root biomass and RDMC) of aspen in the top mineral soil with that of spruce in the organic layer pointed to the use of an intensive resource acquisition strategy by aspen in the mineral layer. This observation supported the hypothesis suggesting more contrasting rooting patterns along the soil profile with mixing of species (H5).

We found an increase of spruce FRB in pure stands in response to lower nutrient availability, and its decline in mixed stands as a result of increased nutrient availability compared to pure stands (Figure 5a). This indicated an anisotropic response of spruce root biomass production towards nutrient-rich patches of soil [41]. The higher spruce FRB in the organic and top mineral horizon in pure stands, compared to mixed stands (Figure 2a), suggested more stressful conditions for spruce in pure stands [73]. This situation may result from nitrogen limitation [74] and competition with mosses and ericaceous species [61,75]. Mosses and Ericaceae were more abundant in pure spruce stands, while they were only found in small patches in mixed stands (field observations). Both groups immobilize and cycle nutrients at the top of the organic layer, making them less accessible to trees [10,76]. In mixed stands, the higher root and litter turnover (short lifespan and high decomposition rate) of vascular plants [77] and aspen $[47,73]$ maintain a higher fertility within the organic layer [10,78-81], thereby modulating interspecific competition among understory plants and trees. The higher turnover of aspen roots in the organic layer results mainly from their lower RDMC, common to deciduous species in temperate and boreal forests $[80,82,83]$.

The shift in spruce rooting patterns between pure and mixed stands (Figures 4 and 5a) points to its plastic response to nutrient availability and competition (morphological plasticity, census Bradshaw [84]), which is indicative of the use of both intensive and extensive nutrient uptake strategies [53]. An intensive strategy is generally associated with low $\mathrm{C}$ cost for root production to the plant, and the reverse for the extensive strategy (higher $C$ cost to the plant) $[54,55]$. The spruce intensive strategy prevails in mixed stands, and resulted in lower FRB (Figure 2a) and higher RDMC 
(Figure 4) in the organic layer of mixed stands, as compared to pure stands. This indicates a reduced carbon allocation into root biomass $[85,86]$. In pure stands, the extensive strategy exhibited itself through higher spruce FRB, its strong and negative correlation with nutrient content $\left(\mathrm{N}, \mathrm{NH}_{4}, \mathrm{~K}, \mathrm{CEC}\right)$, and higher RDMC in both the organic and the top mineral layers (Figure 6) $[42,48,49]$.

The decline in spruce root biomass in mixed stands might also indicate a higher competitive ability of aspen in these stands, as has been suggested for mixed Norway spruce (Picea abies (L.) H. Karst) and beech (Fagus sylvatica L.) stands in Europe [87]. The intersite variability observed in the rooting patterns of spruce in mixed stands (Figure 5a) might indicate that the interspecific competition may increase with a higher aspen basal area. However, the limited number of sites in our study did not allow us to test such a hypothesis. To do so, it would be necessary to increase the sampling size to ensure adequate coverage of a range of canopy compositions. We speculate that the negative impact of aspen on spruce nutrient uptake would be minimal, due to the facilitative effect of aspen on soil nutrient availability compared to multiple competitive mechanisms (intraspecific competition, interference with Ericaceae and nutrient immobilization by moss layer) which are at play in pure stands [88].

The lack of a strong correlation between aspen FRB, RDMC, and nutrients in the organic layer in both types of stands (Figure $5 b$ and Figure S1) suggested a strong selective placement of aspen roots within soil patches, pointing to an extensive nutrient uptake strategy [89]. A similar lack of correlations has been reported for aspen in pure aspen and mixed jack pine-aspen stands [47], two deep-rooted boreal species.

Aspen responded to tree species mixture by a greater allocation of roots to the mineral horizon (Figure 2), apparently avoiding competition with spruce in the organic layer [90]. The increasing aspen FRB and its higher RDMC in the mineral horizon, as well as the similarity between these rooting patterns of spruce with those of spruce as observed in the organic layer of mixed stands, pointed to an intensive strategy in nutrient acquisition [53]. Under such a strategy, roots exhibit competition avoidance, which generally leads to the specialization of the part of the root system free from interspecific competition in the uptake of locally abundant resources [91-93]. Indeed, a higher nutrient content in the mineral soil of mixed stands (Table S1) and their correlation with aspen FRB indicated that aspen nutrient uptake mainly takes place in the mineral horizon in mixed stands. This corroborates the significant correlation observed between the natural isotopic abundance of $\mathrm{N}$ in aspen leaves and that of the top mineral soil in mixed stands and the lack of such correlation in pure aspen stands (Ghotsa et al. unpublished data). However, it should be noted that, overall, compared to total root biomass of aspen in pure stands, the increased root biomass of aspen in mixed stands might suggest that aspen would allocate more biomass to fine roots compared to aboveground biomass in the mixed stands. These results suggest that two species with different types of root foraging strategies and competitive ability are more likely to coexist in a heterogeneous environment [94].

Mycorrhizae also play an important role in the nutrition of trees species in boreal forests. Spruce and aspen are known as obligate mycorrhizal species, with spruce linking exclusively with ectomycorrhizae [95], and aspen with both ecto-and arbuscular mycorrhizae [96]. They extend the uptake zone of their host beyond their root-soil interface, and their diversity and uptake capacity varies with stand tree species composition [69,97]. Although they were not studied here, a good understanding of their composition and distribution along the soil profile might be critical for an appropriate characterization of belowground interactions between spruce and aspen in mixed stands.

\section{Conclusions}

Overall, the results suggest that spruce and aspen accentuate their differences in rooting depth when mixed together. The process is likely controlled by tree-soil feedbacks and the intensity of interspecific competition, as has been suggested [87,98-101]. We provide new insight into underground interactions between the two species in boreal mixedwoods in northwestern Quebec, supporting the hypothesis of a competitive exclusion of aspen by spruce, as suggested in earlier studies [24], while emphasizing that the hypothesis is valid only in the organic layer of the soil. The facilitative 
effect of aspen on nutrient availability, however, might contribute to minimizing the impact of spruce competitive pressure on aspen. Aspen respond to mixing by increasing their root biomass in the mineral soil, and the process likely contributes to a partitioning of the use of soil resources by both species along the soil profile. These findings, therefore, suggest that spruce may benefit from the presence of aspen by increasing its nutrient uptake in the organic soil layer while not limiting aspen nutrients acquisition. We speculate, based on the concept of "functional equilibrium", that increased spruce nutrient uptake in mixed stands would lead to higher aboveground total stand biomass. The observation that mixed spruce-aspen stands have a higher volume of spruce merchantable biomass, compared to pure spruce stands [25], is in agreement with this hypothesis.

Supplementary Materials: The following are available online at http://www.mdpi.com/1999-4907/11/2/127/s1, Figure S1. Variation in (A) fine root biomass and (B) root dry matter content of black spruce and trembling aspen with soil C:N ratio, total $\mathrm{N}$, ammonium, phosphorus, potassium exchangeable cations (CEC) concentration within the three soil horizon layers in pure and mixed stands, Table S1. Summary of soil chemical properties (mean and SEM), Table S2. Effect $p$ values of the analysis of covariance for spruce, Table S3. Effect $p$.values of the analysis of covariance for aspen.

Author Contributions: Conceptualization and Methodology, C.G.M., D.H., Y.B., and I.D.; Data curation and formal analysis, C.G.M.; Funding acquisition, I.D.; Supervision, D.H., and I.D.; Writing-original draft, C.G.M.; Writing-review and editing, C.G.M., D.H., Y.B., and I.D. All authors have read and agreed to the published version of the manuscript.

Funding: This study was supported by the NSERC-UQAT-UQAM Industrial Chair in Sustainable Forest Management. Financial support was also provided by a MITACS Accelerate grant to I.D. as part of the project "Can tree species mixing improve resilience and productivity of boreal forests?" in partnership with OURANOS, the Consortium on Regional Climatology and Adaptation to Climate Change of Canada.

Acknowledgments: We thank Lauriane Navarro, Rébecca Hétu-Le François and Danielle Charron for field assistance as well as Margot Archambeault for help in the laboratory. We also thank Mélanie DesRochers of the Centre d'étude de la forêt (CEF) for the map of the study sites. We are grateful to two anonymous reviewers who significantly contributed to improving the quality of this paper.

Conflicts of Interest: The authors declare no conflict of interest.

\section{References}

1. Liang, J.; Crowther, T.W.; Picard, N.; Wiser, S.; Zhou, M.; Alberti, G.; Schulze, E.D.; McGuire, A.D.; Bozzato, F.; Pretzsch, H.; et al. Positive biodiversity-productivity relationship predominant in global forests. Science 2016, 354, aaf8957. [CrossRef]

2. Zhang, Y.; Chen, H.Y.H.; Taylor, A.R. Positive species diversity and above-ground biomass relationships are ubiquitous across forest strata despite interference from overstorey trees. Funct. Ecol. 2016, 31, 419-426. [CrossRef]

3. Zhang, Y.; Chen, H.Y.H.; Reich, P.B. Forest productivity increases with evenness, species richness and trait variation: A global meta-analysis. J. Ecol. 2012, 100, 742-749. [CrossRef]

4. Morin, X.; Fahse, L.; Scherer-Lorenzen, M.; Bugmann, H. Tree species richness promotes productivity in temperate forests through strong complementarity between species: Species richness promotes forest productivity. Ecol. Lett. 2011, 14, 1211-1219. [CrossRef] [PubMed]

5. Ratcliffe, S.; Holzwarth, F.; Nadrowski, K.; Levick, S.; Wirth, C. Tree neighbourhood matters-Tree species composition drives diversity-productivity patterns in a near-natural beech forest. For. Ecol. Manag. 2015, 335, 225-234. [CrossRef]

6. Roscher, C.; Schumacher, J.; Gubsch, M.; Lipowsky, A.; Weigelt, A.; Buchmann, N.; Schmid, B.; Schulze, E.-D. Using Plant Functional Traits to Explain Diversity-Productivity Relationships. PLoS ONE 2012, 7, e36760. [CrossRef] [PubMed]

7. Ruiz-Benito, P.; Gómez-Aparicio, L.; Paquette, A.; Messier, C.; Kattge, J.; Zavala, M.A. Diversity increases carbon storage and tree productivity in Spanish forests: Diversity effects on forest carbon storage and productivity. Glob. Ecol. Biogeogr. 2014, 23, 311-322. [CrossRef]

8. Franklin, J.F.; Van Pelt, R. Spatial aspects of structural complexity in old-growth forests. J. For. 2004, 102, $22-28$. 
9. Hunter, M.L. Maintaining Biodiversity in Forest Ecosystems, 1st ed.; Cambridge University Press: Cambridge, UK; New York, NY, USA, 1999; ISBN 0-521-63104-1.

10. Légaré, S.; Paré, D.; Bergeron, Y. Influence of Aspen on Forest Floor Properties in Black Spruce-dominated Stands. Plant Soil 2005, 275, 207-220. [CrossRef]

11. Lei, X.; Wang, W.; Peng, C. Relationships between stand growth and structural diversity in spruce-dominated forests in New Brunswick, Canada. Can. J. For. Res. 2009, 39, 1835-1847. [CrossRef]

12. Paquette, A.; Messier, C. The effect of biodiversity on tree productivity: From temperate to boreal forests. Glob. Ecol. Biogeogr. 2011, 20, 170-180. [CrossRef]

13. Wang, W.; Lei, X.; Ma, Z.; Kneeshaw, D.D.; Peng, C. Positive relationship between aboveground carbon stocks and structural diversity in spruce-dominated forest stands in New Brunswick, Canada. For. Sci. 2011, 57, 506-515.

14. Aussenac, R.; Bergeron, Y.; Ghotsa Mekontchou, C.; Gravel, D.; Pilch, K.; Drobyshev, I. Intraspecific variability in growth response to environmental fluctuations modulates the stabilizing effect of species diversity on forest growth. J. Ecol. 2016, 105, 1010-1020. [CrossRef]

15. Morin, X.; Fahse, L.; de Mazancourt, C.; Scherer-Lorenzen, M.; Bugmann, H. Temporal stability in forest productivity increases with tree diversity due to asynchrony in species dynamics. Ecol. Lett. 2014, 17, 1526-1535. [CrossRef] [PubMed]

16. Yachi, S.; Loreau, M. Biodiversity and ecosystem productivity in a fluctuating environment: The insurance hypothesis. Proc. Natl. Acad. Sci. USA 1999, 96, 1463-1468. [CrossRef] [PubMed]

17. Cavard, X.; Bergeron, Y.; Chen, H.Y.H.; Paré, D. Mixed-species effect on tree aboveground carbon pools in the east-central boreal forests. Can. J. For. Res. 2010, 40, 37-47. [CrossRef]

18. Chen, H.Y.; Klinka, K.; Mathey, A.H.; Wang, X.; Varga, P.; Chourmouzis, C. Are mixed-species stands more productive than single-species stands: An empirical test of three forest types in British Columbia and Alberta. Can. J. For. Res. 2003, 33, 1227-1237. [CrossRef]

19. Drobyshev, I.; Gewehr, S.; Berninger, F.; Bergeron, Y. Species specific growth responses of black spruce and trembling aspen may enhance resilience of boreal forest to climate change. J. Ecol. 2013, 101, 231-242. [CrossRef]

20. Cavard, X.; Bergeron, Y.; Chen, H.Y.H.; Paré, D.; Laganière, J.; Brassard, B. Competition and facilitation between tree species change with stand development. Oikos 2011, 120, 1683-1695. [CrossRef]

21. Filipescu, C.N.; Comeau, P.G. Competitive interactions between aspen and white spruce vary with stand age in boreal mixedwoods. For. Ecol. Manag. 2007, 247, 175-184. [CrossRef]

22. Armstrong, G.W. Considerations for boreal mixedwood silviculture: A view from the dismal science. For. Chron. 2014, 90, 44-49. [CrossRef]

23. Zhang, D.; Pearse, P.H. Forest Economics; UBC Press: Vancouver, BC, Canada, 2012; ISBN 978-0-7748-2153-7.

24. Bergeron, Y.; Chen, H.Y.; Kenkel, N.C.; Leduc, A.L.; Macdonald, S.E. Boreal mixedwood stand dynamics: Ecological processes underlying multiple pathways. For. Chron. 2014, 90, 202-213. [CrossRef]

25. Légaré, S.; Paré, D.; Bergeron, Y. The responses of black spruce growth to an increased proportion of aspen in mixed stands. Can. J. For. Res. 2004, 34, 405-416. [CrossRef]

26. Statistics Canada. Human Activity and the Environment 2017. Can. Public Policy Anal. Polit. 2018, 4, 587. [CrossRef]

27. Wirth, C. Fire Regime and Tree Diversity in Boreal Forests: Implications for the Carbon Cycle. In Forest Diversity and Function; Scherer-Lorenzen, M., Körner, C., Schulze, E.D., Eds.; Springer: Berlin/Heidelberg, Germany, 2005; Volume 176, pp. 309-344. ISBN 3-540-22191-3.

28. Bergeron, Y.; Leduc, A.; Joyal, C.; Morin, H. Balsam fir mortality following the last spruce budworm outbreak in northwestern Quebec. Can. J. For. Res. 1995, 25, 1375-1384. [CrossRef]

29. Bouchard, M.; Kneeshaw, D.; Bergeron, Y. Forest dynamics after successive spruce budworm outbreaks in mixedwood forests. Ecology 2006, 87, 2319-2329. [CrossRef]

30. McKenney, D.W.; Pedlar, J.H.; Lawrence, K.; Campbell, K.; Hutchinson, M.F. Potential Impacts of Climate Change on the Distribution of North American Trees. BioScience 2007, 57, 939-948. [CrossRef]

31. McKenney, D.W.; Pedlar, J.H.; Rood, R.B.; Price, D. Revisiting projected shifts in the climate envelopes of North American trees using updated general circulation models. Glob. Chang. Biol. 2011, 17, 2720-2730. [CrossRef]

32. Callaway, R.M. The detection of neighbors by plants. Trends Ecol. Evol. 2002, 17, 104-105. [CrossRef] 
33. Kuebbing, S.E.; Nuñez, M.A. Negative, neutral, and positive interactions among nonnative plants: Patterns, processes, and management implications. Glob. Chang. Biol. 2015, 21, 926-934. [CrossRef]

34. Callaway, R.M. Positive interactions among plants. Bot. Rev. 1995, 61, 306-349. [CrossRef]

35. Callaway, R.M.; Brooker, R.W.; Choler, P.; Kikvidze, Z.; Lortie, C.J.; Michalet, R.; Paolini, L.; Pugnaire, F.I.; Newingham, B.; Aschehoug, E.T.; et al. Positive interactions among alpine plants increase with stress. Nature 2002, 417, 844-848. [CrossRef] [PubMed]

36. De Kroon, H.; Hendriks, M.; van Ruijven, J.; Ravenek, J.; Padilla, F.M.; Jongejans, E.; Visser, E.J.W.; Mommer, L. Root responses to nutrients and soil biota: Drivers of species coexistence and ecosystem productivity. J. Ecol. 2012, 100, 6-15. [CrossRef]

37. De Kroon, H.; Mommer, L.; Nishiwaki, A. Root Competition: Towards a Mechanistic Understanding. In Root Ecology; de Kroon, H., Visser, E.J.W., Eds.; Springer: Berlin/Heidelberg, Germany, 2003; Volume 168, pp. 215-234. ISBN 978-3-642-05520-1. [CrossRef]

38. Goldberg, D.E. Components of resource competition in plant communities. Perspect. Plant Compet. 1990, $27-49$.

39. Holzapfel, C.; Mahall, B.E. Bidirectional facilitation and interference between shrubs and annuals in the Mojave Desert. Ecology 1999, 80, 1747-1761. [CrossRef]

40. Pregitzer, K.S.; DeForest, J.L.; Burton, A.J.; Allen, M.F.; Ruess, R.W.; Hendrick, R.L. Fine root architecture of nine North American trees. Ecol. Monogr. 2002, 72, 293-309. [CrossRef]

41. Brassard, B.W.; Chen, H.Y.H.; Bergeron, Y. Influence of Environmental Variability on Root Dynamics in Northern Forests. Crit. Rev. Plant Sci. 2009, 28, 179-197. [CrossRef]

42. Craine, J.M. Reconciling plant strategy theories of Grime and Tilman. J. Ecol. 2005, 93, 1041-1052. [CrossRef]

43. Lõhmus, K.; Truu, J.; Truu, M.; Kaar, E.; Ostonen, I.; Alama, S.; Kuznetsova, T.; Rosenvald, K.; Vares, A.; Uri, V.; et al. Black alder as a promising deciduous species for the reclaiming of oil shale mining areas. In Proceedings of the Brownfields III: Prevention, Assessment, Rehabilitation and Development of Brownfield Sites, Tallin, Estonia, 2006; WIT Press: Southampton, UK, 2006; Volume 94, pp. 87-98. [CrossRef]

44. Ostonen, I.; Lohmus, K.; Helmisaari, H.S.; Truu, J.; Meel, S. Fine root morphological adaptations in Scots pine, Norway spruce and silver birch along a latitudinal gradient in boreal forests. Tree Physiol. 2007, 27, 1627-1634. [CrossRef] [PubMed]

45. White, P.J.; George, T.S.; Dupuy, L.X.; Karley, A.J.; Valentine, T.A.; Wiesel, L.; Wishart, J. Root traits for infertile soils. Front. Plant Sci. 2013, 4. [CrossRef]

46. Ostonen, I.; Püttsepp, Ü.; Biel, C.; Alberton, O.; Bakker, M.R.; Lõhmus, K.; Majdi, H.; Metcalfe, D.; Olsthoorn, A.F.M.; Pronk, A.; et al. Specific root length as an indicator of environmental change. Plant Biosyst. Int. J. Deal. Asp. Plant Biol. 2007, 141, 426-442. [CrossRef]

47. Brassard, B.W.; Chen, H.Y.H.; Cavard, X.; Laganière, J.; Reich, P.B.; Bergeron, Y.; Paré, D.; Yuan, Z. Tree species diversity increases fine root productivity through increased soil volume filling. J. Ecol. 2013, 101, 210-219. [CrossRef]

48. Tilman, D. Resource competition and plant traits: A response to Craine et al. 2005. J. Ecol. 2007, 95, $231-234$. [CrossRef]

49. Tilman, D. Resource Competition and Community Structure; Monographs in population biology; Princeton University Press: Princeton, NJ, USA, 1982; ISBN 0-691-08301-0.

50. Grime, J.P. Evidence for the Existence of Three Primary Strategies in Plants and Its Relevance to Ecological and Evolutionary Theory. Am. Nat. 1977, 111, 1169-1194. [CrossRef]

51. Turner, B.L. Resource partitioning for soil phosphorus: A hypothesis. J. Ecol. 2008, 96, 698-702. [CrossRef]

52. Iwasa, Y.; Roughgarden, J. Shoot/root balance of plants: Optimal growth of a system with many vegetative organs. Theor. Popul. Biol. 1984, 25, 78-105. [CrossRef]

53. Grime, J.P.; Crick, J.; Rincon, J. The ecological significance of plasticity. Symp. Soc. Exp. Biol. 1986, 40, 5-29.

54. Lõhmus, K.; Oja, T.; Lasn, R. Specific root area: A soil characteristic. Plant Soil 1989, 119, 245-249. [CrossRef]

55. Addo-Danso, S.D.; Prescott, C.E.; Adu-Bredu, S.; Duah-Gyamfi, A.; Moore, S.; Guy, R.D.; Forrester, D.I.; Owusu-Afriyie, K.; Marshall, P.L.; Malhi, Y. Fine-root exploitation strategies differ in tropical old growth and logged-over forests in Ghana. Biotropica 2018, 50, 606-615. [CrossRef]

56. Veillette, J.J. Evolution and paleohydrology of glacial Lakes Barlow and Ojibway. Quat. Sci. Rev. 1994, 13, 945-971. [CrossRef] 
57. Environment Canada. Canadian Climate Normals 1971-2000. Available online: http://climate.wetheroffice. gc.ca/climate_normals/index_e.html (accessed on 12 January 2019).

58. Brais, S.; Camiré, C. Keys for soil moisture regime evaluation for northwestern Quebec. Can. J. For. Res. 1992, 22, 718-724. [CrossRef]

59. Ma, Z.; Chen, H.Y.H. Effects of species diversity on fine root productivity increase with stand development and associated mechanisms in a boreal forest. J. Ecol. 2017, 105, 237-245. [CrossRef]

60. Ministère des Forêts de la Faune et des Parcs (MFFP). Norme de Stratification Ecoforestière du Quatrième Inventaire Ecoforestier du Québec Méridional. 2015, 111. Available online: http://collections.banq.qc.ca/ark: /52327/2748275 (accessed on 11 June 2019).

61. Pacé, M.; Fenton, N.J.; Paré, D.; Bergeron, Y. Ground-layer composition affects tree fine root biomass and soil nutrient availability in jack pine and black spruce forests under extreme drainage conditions. Can. J. For. Res. 2017, 47, 433-444. [CrossRef]

62. Houle, D.; Moore, J.D.; Ouimet, R.; Marty, C. Tree species partition N uptake by soil depth in boreal forests. Ecology 2014, 95, 1127-1133. [CrossRef]

63. Birouste, M.; Zamora-Ledezma, E.; Bossard, C.; Pérez-Ramos, I.M.; Roumet, C. Measurement of fine root tissue density: A comparison of three methods reveals the potential of root dry matter content. Plant Soil 2014, 374, 299-313. [CrossRef]

64. Carter, M.R.; Gregorich, E.G. Soil Sampling and Methods of Analysis, 2nd ed.; Canadian Society of Soil Science; CRC Press: Pinawa, MB, Canada; Boca Raton, FL, USA, 2008; ISBN 978-0-8493-3586-0.

65. Mehlich, A. Mehlich 3 soil test extractant: A modification of Mehlich 2 extractant. Commun. Soil Sci. Plant Anal. 1984, 15, 1409-1416. [CrossRef]

66. Brassard, B.W.; Chen, H.Y.H.; Bergeron, Y.; Paré, D. Differences in fine root productivity between mixed- and single-species stands: Fine root productivity in boreal forest. Funct. Ecol. 2011, 25, 238-246. [CrossRef]

67. Loreau, M.; Hector, A. Partitioning selection and complementarity in biodiversity experiments. Nature 2001, 412, 72-76. [CrossRef]

68. Zobel, M.; Zobel, K. Studying plant competition: From root biomass to general aims. Studying plant competition. J. Ecol. 2002, 90, 578-580. [CrossRef]

69. Pierret, A.; Maeght, J.L.; Clément, C.; Montoroi, J.P.; Hartmann, C.; Gonkhamdee, S. Understanding deep roots and their functions in ecosystems: An advocacy for more unconventional research. Ann. Bot. 2016, 118, 621-635. [CrossRef]

70. Roumet, C.; Birouste, M.; Picon-Cochard, C.; Ghestem, M.; Osman, N.; Vrignon-Brenas, S.; Cao, K.; Stokes, A. Root structure-function relationships in 74 species: Evidence of a root economics spectrum related to carbon economy. New Phytol. 2016, 210, 815-826. [CrossRef] [PubMed]

71. McDonald, J.H. Handbook of Biological Statistics, 3rd ed.; Sparky House Publishing: Baltimore, MD, USA, 2014; Volume 2014.

72. R Core Team. R: A Language and Environment for Statistical Computing; R Foundation for Statistical Computing: Vienna, Austria, 2016.

73. Steele, S.J.; Gower, S.T.; Vogel, J.G.; Norman, J.M. Root mass, net primary production and turnover in aspen, jack pine and black spruce forests in Saskatchewan and Manitoba, Canada. Tree Physiol. 1997, 17, 577-587. [CrossRef] [PubMed]

74. Tamm, C.O. Nitrogen in Terrestrial Ecosystems: Questions of Productivity, Vegetational Changes, and Ecosystem Stability; Springer: Berlin/Heidelberg, Germany, 1991; ISBN 978-3-642-75168-4.

75. Zackrisson, O.; Nilsson, M.-C.; Dahlberg, A.; Jäderlund, A.; Jaderlund, A. Interference Mechanisms in Conifer-Ericaceae-Feathermoss Communities. Oikos 1997, 78, 209. [CrossRef]

76. Schenk, H.J. Root competition: Beyond resource depletion. Root competition: Beyond resource depletion. J. Ecol. 2006, 94, 725-739. [CrossRef]

77. Pellegrini, A.F.A.; Ahlström, A.; Hobbie, S.E.; Reich, P.B.; Nieradzik, L.P.; Staver, A.C.; Scharenbroch, B.C.; Jumpponen, A.; Anderegg, W.R.L.; Randerson, J.T.; et al. Fire frequency drives decadal changes in soil carbon and nitrogen and ecosystem productivity. Nature 2017, 553, 194-198. [CrossRef]

78. Cavard, X.; Macdonald, S.E.; Bergeron, Y.; Chen, H.Y.H. Importance of mixedwoods for biodiversity conservation: Evidence for understory plants, songbirds, soil fauna, and ectomycorrhizae in northern forests. Environ. Rev. 2011, 19, 142-161. [CrossRef] 
79. Légaré, S.; Bergeron, Y.; Leduc, A.; Paré, D. Comparison of the understory vegetation in boreal forest types of southwest Quebec. Can. J. Bot. 2001, 79, 1019-1027. [CrossRef]

80. McClaugherty, C.A.; Aber, J.D.; Melillo, J.M. The Role of Fine Roots in the Organic Matter and Nitrogen Budgets of Two Forested Ecosystems. Ecology 1982, 63, 1481-1490. [CrossRef]

81. Vogt, K.A.; Vogt, D.J.; Bloomfield, J. Input of Organic Matter to the Soil by Tree Roots. In Developments in Agricultural and Managed Forest Ecology; Elsevier: Amsterdam, The Netherlands, 1991; Volume 24, pp. 171-190. ISBN 978-0-444-89104-4. [CrossRef]

82. Morrow, R.R. Periodicity and growth of sugar maple surface layer roots. J. For. 1950, 48, 875-881.

83. Paula, S.; Pausas, J.G. Root traits explain different foraging strategies between resprouting life histories. Oecologia 2011, 165, 321-331. [CrossRef]

84. Bradshaw, A.D. Evolutionary Significance of Phenotypic Plasticity in Plants. In Advances in Genetics; Caspari, E.W., Thoday, J.M., Eds.; Academic Press: New York, NY, USA, 1965; Volume 13, pp. 115-155. ISBN 978-0-12-017613-7. [CrossRef]

85. Bauhus, J.; Messier, C. Soil exploitation strategies of fine roots in different tree species of the southern boreal forest of eastern Canada. Can. J. For. Res. 1999, 29, 260-273. [CrossRef]

86. Eissenstat, D.M.; Kucharski, J.M.; Zadworny, M.; Adams, T.S.; Koide, R.T. Linking root traits to nutrient foraging in arbuscular mycorrhizal trees in a temperate forest. New Phytol. 2015, 208, 114-124. [CrossRef] [PubMed]

87. Schmid, I. The influence of soil type and interspecific competition on the fine root system of Norway spruce and European beech. Basic Appl. Ecol. 2002, 3, 339-346. [CrossRef]

88. Peltzer, D.A.; Wilson, S.D.; Gerry, A.K. Competition Intensity along a Productivity Gradient in a Low-Diversity Grassland. Am. Nat. 1998, 151, 465-476. [CrossRef] [PubMed]

89. Campbell, B.D.; Grime, J.P.; Mackey, J.M.L. A trade-off between scale and precision in resource foraging. Oecologia 1991, 87, 532-538. [CrossRef] [PubMed]

90. Grams, T.E.E.; Andersen, C.P. Competition for Resources in Trees: Physiological Versus Morphological Plasticity. In Progress in Botany; Esser, K., Löttge, U., Beyschlag, W., Murata, J., Eds.; Springer: Berlin/Heidelberg, Germany, 2007; Volume 68, pp. 356-381. ISBN 978-3-540-36830-4. [CrossRef]

91. Hutchings, M.J.; Wijesinghe, D.K. Patchy habitats, division of labour and growth dividends in clonal plants. Trends Ecol. Evol. 1997, 12, 390-394. [CrossRef]

92. Stuefer, J.F. Two types of division of labour in clonal plants: Benefits, costs and constraints. Perspect. Plant Ecol. Evol. Syst. 1998, 1, 47-60. [CrossRef]

93. Stuefer, J.F.; de Kroon, H.; During, H.J. Exploitation of environmental Hetergeneity by Spatial Division of Labor in a Clonal Plant. Funct. Ecol. 1996, 10, 328. [CrossRef]

94. Hutchings, M.J.; John, E.A.; Wijesinghe, D.K. Toward understanding the consequences of soil heterogeneity for plant populations and communities. Ecology 2003, 84, 2322-2334. [CrossRef]

95. Robertson, S.J.; Tackaberry, L.E.; Egger, K.N.; Massicotte, H.B. Ectomycorrhizal fungal communities of black spruce differ between wetland and upland forests. Can. J. For. Res. 2006, 36, 972-985. [CrossRef]

96. Neville, J.; Tessier, J.L.; Morrison, I.; Scarratt, J.; Canning, B.; Klironomos, J.N. Soil depth distribution of ectoand arbuscular mycorrhizal fungi associated with Populus tremuloides within a 3-year-old boreal forest clear-cut. Appl. Soil Ecol. 2002, 19, 209-216. [CrossRef]

97. Kalliokoski, T.; Pennanen, T.; Nygren, P.; Sievänen, R.; Helmisaari, H.S. Belowground interspecific competition in mixed boreal forests: Fine root and ectomycorrhiza characteristics along stand developmental stage and soil fertility gradients. Plant Soil 2010, 330, 73-89. [CrossRef]

98. Berger, T.W.; Sun, B.; Glatzel, G. Soil seed banks of pure spruce (Picea abies) and adjacent mixed species stands. Plant Soil 2004, 264, 53-67. [CrossRef]

99. Berger, T.W.; Untersteiner, H.; Toplitzer, M.; Neubauer, C. Nutrient fluxes in pure and mixed stands of spruce (Picea abies) and beech (Fagus sylvatica). Plant Soil 2009, 322, 317-342. [CrossRef] 
100. Bhatti, J.S.; Foster, N.W.; Hazlett, P.W. Fine root biomass and nutrient content in a black spruce peat soil with and without alder. Can. J. Soil Sci. 1998, 78, 163-169. [CrossRef]

101. Rosengren, U.; Göransson, H.; Jönsson, U.; Stjernquist, I.; Thelin, G.; Wallander, H. Functional Biodiversity Aspects on the Nutrient Sustainability in Forests-Importance of Root Distribution. J. Sustain. For. 2006, 21, 77-100. [CrossRef]

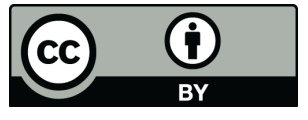

(C) 2020 by the authors. Licensee MDPI, Basel, Switzerland. This article is an open access article distributed under the terms and conditions of the Creative Commons Attribution (CC BY) license (http://creativecommons.org/licenses/by/4.0/). 